\title{
QMS in the consulting engineering industry - can we do better?
}

\author{
Helgi Pór Ingason $^{\mathrm{a}}{ }^{1}$, Sveinn Thor Hallgrimsson ${ }^{\mathrm{b}}$
}

${ }^{a}$ School of Science and Engineering at Reykjavík University, Reykjavík, Iceland 'benior consultant at Sevo, Reykjavík, Iceland Fyrirspurnir:

Helgi Pór Ingason

helgithor@ru.is

Greinin barst 14. janúar 2017

Sambykkt til birtingar 15. júní 2017

Sú breyting hefur orðið á starfi íslenskra verkfræðistofa á undanförnum árum að flestar beirra eru vottaðar samkvæmt ISO 9001 stjórnunarstaðlinum. Í pessari grein er fjallað um pessa umbreytingu úr premur mismunandi sjónarhornum. Í fyrsta lagi með viðtölum við gæðastjóra og stjórnendur fimm verkfræðistofa hvar $80 \%$ ráðgjafarverkfræðinga hér á landi starfa. Í öðru lagi með könnun sem gerð var meðal allra starfsmanna sömu verkfræðistofa. Í priðja lagi með viðtölum við fulltrúa fimm stóra verkkaupa pessara verkfræðistofa, sem allir eru opinber fyrirtæki eða stofnanir. Fulltrúar og starfsmenn verkfræðistofanna eru jákvæðir í afstöðu sinni til ISO 9001 vottunar og reynsla peirra af vottuninni er jafnvel enn betri en pær væntingar sem gerðar voru í upphafi. Verkkauparnir eru hlutlausari í afstöðu sinni og virðast oft taka vottun verkfræðistofanna sem sjálfsögðum hlut. Engu aðे síður er pað jafnan lykilatriði fyrir pessa verkkaupa að verkfræðistofur, sem fyrir pá starfa, séu vottaðar samkvæmt ISO 9001 staðli. Vottuð fyrirtæki purfa að stunda stöðugt umbótastarf til að aðlaga og bæta gæðakerfi sín og pau purfa að tryggja að stjórnendur, starfsmenn og viðskiptavinir upplifi árangur af pessu umbótastarfi.

Lykilorð: Gæðastjórnunarkerfi, ISO 9001, verkfræðistofur, vottun.
The consulting engineering industry in Iceland has transformed itself in recent years to the extent that ISO 9001 certification has now been widely achieved. This paper explores aspects of this transformation from three different perspectives: Firstly through interviews with quality managers and executives of five engineering firms employing $80 \%$ of consulting engineers in Iceland; secondly through a survey conducted among all employees of the same engineering firms; and thirdly through interviews with representatives of five major public purchasers of engineering services in this country. The representatives and employees of the engineering consultancies are quite positive about the benefits of their ISO 9001 certification and that their experiences have surpassed their expectations. The public clients are more neutral in how they view the same topic and often seem to take certification for granted. Nevertheless, it is normally a key requirement for these public clients that companies tendering for larger projects have to have ISO 9001. Certified companies need to adapt and continuously improve their quality systems and make the benefits of this known to management, employees and clients, as appropriate. Keywords: QMS, ISO 9001, Engineering consultancies, certification.

\section{INTRODUCTION}

The Association of Chartered Engineers in Iceland was formed in 1912 and the work of member engineers in the following decades was a vital element in the revolutionary modernisation of Iceland (Thordarson, 2002). Much of this early work involved building up the transport infrastructure, and the development of water, sewerage, electricity, heating and communications infrastructure, alongside large-scale building programmes. During these earlier times, most engineers would have been employed by the public sector, while more and more private sector engineering consultancies gradually developed over time. Those in the private sector were relatively small until the last years of the 20th century when some of them began to merge, mainly to be able to undertake larger projects. Since this time, the larger engineering consultancies have broadened their scope and successfully developed overseas markets for their engineering services that are now truly global. Implementing best practice for quality management systems and achieving widespread ISO 9001 certification has been carried out in conjunction with this recent development. This paper sets out to explore different aspects of these changes in quality management approaches and to find answers to the following three main questions:

1. Why did the engineering consultancies decide to implement a Quality Management System (QMS) and what have they gained?

2. What are the perceptions of the employees of the engineering consultancies towards the Quality Management Systems?

3. What are the benefits perceived by clients and how does ISO 9001 certification affect the competitive position of engineering consultancies?

In order to answer these questions, the views of executives, quality managers and employees of large consulting engineering firms, as well as representatives of large clients that purchase their engineering services, were sought.

\section{LITERATURE REVIEW}

ISO 9001 has been implemented by over one million companies and organisations in over 170 countries. The standard is based on a number of quality management principles and helps ensure that customers get consistent, good quality products and services, and that quality is continously improved (ISO, 2017).

FIDIC (International Federation of Consulting Engineers), founded in 1913 by three European national associations of independent consulting engineers, has members operating in 97 countries. In 1997, FIDIC, together with EFCA (European Federation of Engineering Consultancy Associations), issued a guide entitled: Interpretation and Application of the ISO 9001 Standard for the Engineering Consulting Industry. In 2001 this guide was updated to reflect the revised ISO 9001:2000 Standard (FIDIC, 2001).

Many papers have been written on the implementation and operation of ISO 9001, but little can be found specifically on the consulting engineering industry. Tang and Kam (1999) did a survey of ISO 9001 implementation in engineering consultancies in Hong Kong. Their survey results demonstrated that a major reason for attaining ISO 9001 certification was to improve their quality image. In fact, the increase in client satisfaction met the original high expectations of the engineering consultancies. However, they found that the certification could not help in a competetive environment as other consultants were also certified. From a broader perspective, Zeng et al. (2007) explored the barriers to implementation of ISO 9001 in China. They highlighted various problems in implementing the standard that largely revolved around its perception as a mandatory requirement. Only $41 \%$ of the respondents felt that their companies had implemented the ISO 9001 standard seriously and there was widespread over-expectation as to the benefits of certification. Urbonavicius (2005) studied ISO 9001 system implementation in small- and medium-sized companies 
from new EU member countries and found that the main motivation to its implementation is different from the main benefits of implementation - as perceived in retrospect. The motivational arguments are connected with marketing and sales, while the main benefits experienced are linked to aspects such as operational efficiency.

Al-Najjar and Jawad (2011) did an empirical study on ISO 9001 implementation barriers and misconceptions in the service and manufacturing sectors in Iraq. Among other things, a lack of commitment from top management and employee resistance were identified as important barriers to ISO 9001 implementation. According to the findings of Sampaio et al. (2009), ISO 9001 motivations and benefits can be categorised as being external - related to marketing and promotional issues, or internal - related to internal organisational improvements. They conclude that companies maximise their benefits if they achieve ISO 9001 certification based on internal motivations. Lack of involvement by top management is considered to be the main obstacle faced by companies during the implementation and certification of ISO 9001 QMS.

A number of references can be found that assess the impact of ISO 9001 QMS certification on the financial operation of companies. Some authors conclude that there is a direct link between ISO 9001 certification and financial improvement (e.g. Beirã \& Sarsfield, 2002; Wayhan et al., 2002; Sellers \& Nicolau, 2002; Chow-Chua et al., 2003; Naseret al., 2004; Dimara et al., 2004), while others claim that they cannot find evidence to substantiate that hypothesis (e.g. Lima et al., 2000; Aarts \& Vos, 2001; Heras et al., 2001; Martínez-Costa \& Martínez-Lorente, 2003; Corbett et al., 2005).

Hrobjartsson et al. (2013) looked at all ISO 9001 certified companies in Iceland and compared them to similar noncertified companies in an effort to find out if there was a financial benefit from the certification. Certified companies had a significantly higher gross profit and return on sales ratio. Certified companies also had a lower debt ratio than those that were noncertified. Heras et al. (2002) compared certified and noncertified firms, and found significantly better sales growth and profitability in the certified companies. However, when they analysed the difference between pre- and post-registration sales growth and profitability, they found no evidence to support the link between ISO 9001 certification and improvements. They concluded that firms with superior performance are more likely to seek and acquire certification.

Terziovski et al. (2003) pointed out that quality, culture and motivation for adopting ISO 9001 certification are significant predictors of the benefits and values derived from such certification. Furthermore, organisations that gain ISO certification as part of their continuous improvement strategy profited most in terms of performance outcomes. These findings are also supported by Singels et al. (2001).

Gunnlaugsdottir (2010) documents the results of two surveys car- ried out in Iceland in 2001 and 2010 about the reasons and perceived benefits of companies that acquired ISO 9001 certification. The most common incentive for the companies studied was pressure from customers. 39\% of the companies got certified because of government, international or customer requirements, rather than in order to improve quality. Only $11.9 \%$ claimed that they achieved a competitive advantage over other companies after certification.

Ólafsdóttir (2011) examined if contractors in Iceland working in accordance with quality management systems achieved more customer satisfaction than those who did not. She concluded that there is a positive correlation between client's satisfaction with project execution - and whether the corresponding contractor works in accordance with a quality management system.

Brynjarsdottir (2016) studied contractor selection methods in Iceland. Her results show that when Icelandic organisations select contractors, price is by far the most important criteria. Other criteria, for instance whether they work in accordance with a quality management system - do not matter much when clients select contractors.

\section{METHOD}

This study has been carried out in Iceland, a European society limited in size, where it was possible to collect information from the majority of operating engineering consultancies and some of their most important clients. The study was divided into three sections.

Firstly, in-depth interviews were carried out with quality managers and executives of the five largest engineering firms with a combined share of about $80 \%$ in the engineering consultancy market in Iceland. This part of the research focused on the objectives and perceived benefits to these engineering firms of implementation of ISO 9001 QMS.

Secondly, a survey was conducted among all the employees in the same engineering firms. The scope of this survey was approximately $80 \%$ of all privately-employed consulting engineers in Iceland. SurveyMonkey was utilised to conduct the survey based on selected statements sent to all employees of the engineering firms. The objectives were to explore their views on the QMS, to identify the benefits to their firm from the ISO 9001 certification, and collect their perceptions regarding client benefits. The employees were asked to answer a number of statements using a 5-step Likert scale - strongly agree, agree, neutral, disagree, and strongly disagree.

Thirdly, in-depth interviews were carried out with the representatives of five major public bodies that are among the leading purchasers of engineering services in Iceland. The interviews were semi-structured, the questions focusing mainly on the demands these clients place on their suppliers and the quality of the service provided by the engineering firms.

Table 1 An overview of the engineering consultancies interviewed in the study.

\begin{tabular}{|l|l|c|c|}
\hline Company & Profile & Employees & Certified \\
\hline EFLA & $\begin{array}{l}\text { A general engineering and consulting company with widespread international } \\
\text { activities and consultancy (Efla, 2014). }\end{array}$ & 250 & 2004 \\
\hline Mannvit & $\begin{array}{l}\text { An international consulting firm, offering engineering, consulting, management, } \\
\text { operations and EPCM services (Mannvit, 2014) }\end{array}$ & 300 & 2005 \\
\hline Verkís & A consulting firm that provides services in all areas of engineering (Verkís, 2014). & 350 & 2007 \\
\hline VSO & A consultancy offering engineering and management consulting (VSO, 2014). & 50 & 2007 \\
\hline VSB & $\begin{array}{l}\text { An international engineering and consulting firm in the fields of civil, mechanical } \\
\text { and electrical engineering and construction project management (VSB, 2014) }\end{array}$ & 16 & 2011 \\
\hline
\end{tabular}




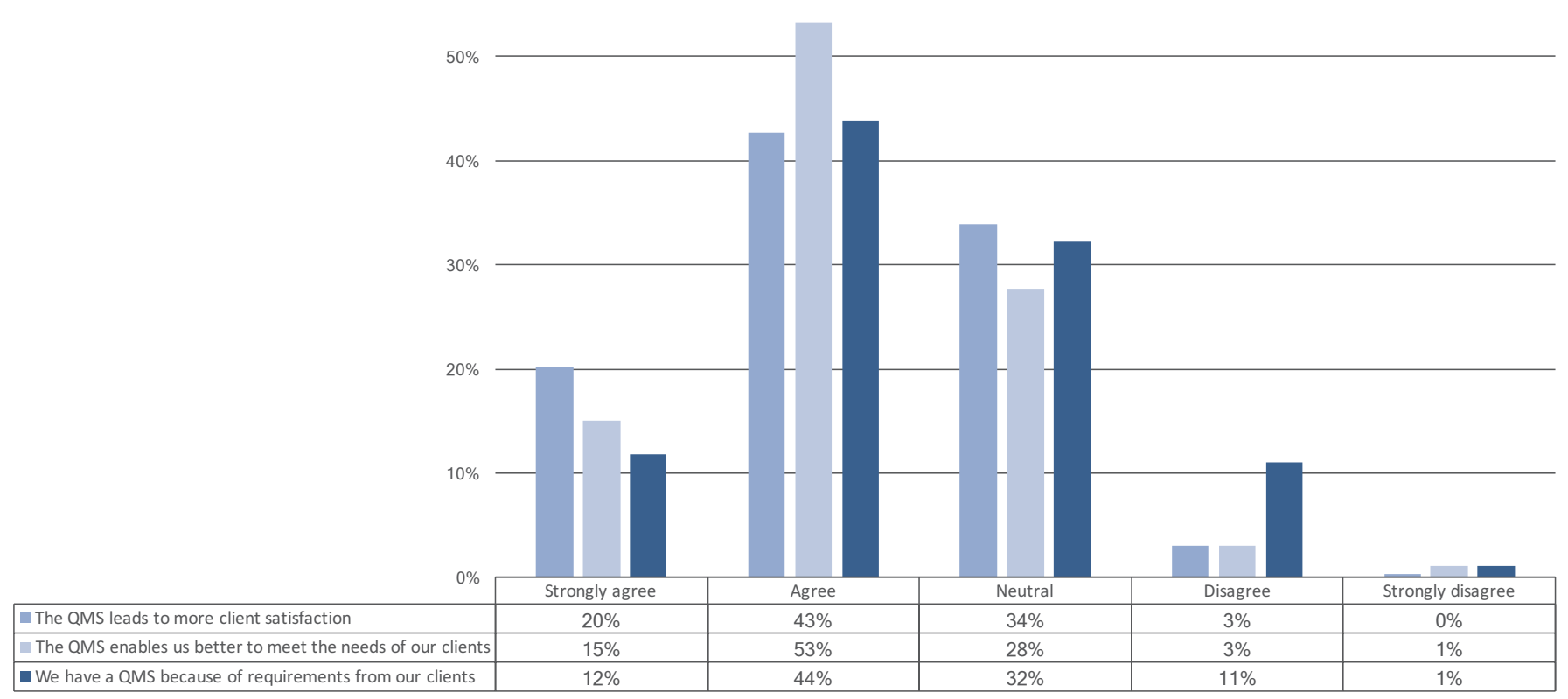

Figure 1 Results from employee survey - answers to statements that relate to clients and their needs.

\section{RESULTS}

\subsection{Interviews with representatives of engineering firms}

Interviews were carried out with representatives of five engineering consultancies in 2013 and 2014. This was a part of a more extensive

study looking at the implementation of quality management systems in Icelandic organisations. The interviewees were quality managers and executives from five companies.

Based on EU standards (EU, 2014) and the number of employees, three of these firms, namely Efla (250 employees), Verkís (350 employees), and Mannvit (300 employees), are classified as large enterprises. VSO Consulting (50 employees) is a medium-sized company, while VSB is a small company.

\section{On what grounds did you decide to implement a QMS?}

The overall key reason for the implementation of QMS in engineering enterprises was that the public sector had included QMS in the criteria to be taken into account in their tendering procedures. Bidders got extra points if they could show a QMS, and additional points if the QMS was certified. This meant that an engineering service could get a contract, even at a higher price, if they had a QMS. Three of the interviewees said that their companies work internationally. Here, one of the reasons for establishing a certified QMS was that this was a condition for being able to operate internationally. They claimed that they would not have been assigned their overseas projects without fulfilling this condition. Further reasons were mentioned, but this seemed to be of the greatest importance. One of the interviewees said that his firm saw the need for a system to help coordinate procedures. Here, the ISO 9001 standard was seen as a new and practical tool, and in addition, the academic community was starting to accept quality management as an academic field. Another one said:

"But equally important is that managers perceived and understood that when a company has become larger than 60 employees, they lose overview, projects become larger and more complex, there is more manpower and increased complexity. This requires a methodology different from what works for small businesses."
What has been the experience of establishing a QMS? Has it brought benefits, more satisfaction for customers, suppliers, employees, increased efficiency or financial economic benefits?

The interviewees were all quite positive towards their ISO 9001 certified QMS. Among other things they mentioned:

- It has made it easier to get project assignments, both domestically and abroad.

- It gives increased credibility, both with employees and customers.

- Employees do not want to return to the time before there was QMS.

- Efficiency, transparency and uniform systems are key outcomes of the QMS.

- The QMS has united the employees.

One of the interviewees phrased his views in a general way and echoed the perceptions of all the representatives of the engineering firms:

\begin{abstract}
"It would not have been possible for us to grow as a company without the QMS and we would not have been eligible participants in many of our most important projects in the last years, both domestically and abroad. The QMS gives important credibility, not only outwards but also inwards; and it is clear that our employees would not like to return to the old times when we did not have a certified QMS. The main benefits are increased efficiency, a uniform and transparent management system, which lead to financial benefits."
\end{abstract}

\subsection{Survey among employees of engineering firms}

The same engineering consultancies as in section 4.1 were surveyed. The total number of employees of these engineering firms is about 970 or approximately $80 \%$ of privately-employed consulting engineers in Iceland. The response rate for the survey was $38.4 \%$. As a first result, $69 \%$ of the employees in the survey agree or strongly agree with the statement that they have a good knowledge of the QMS, 23\% are neutral, while $7 \%$ disagree. Other results are plotted as bar charts (figures 1 and 2) which show the question asked in each case and the employee responses.

$63 \%$ of the employees agree or strongly agree with the statement that the QMS leads to more customer satisfaction, 34\% are neutral, 


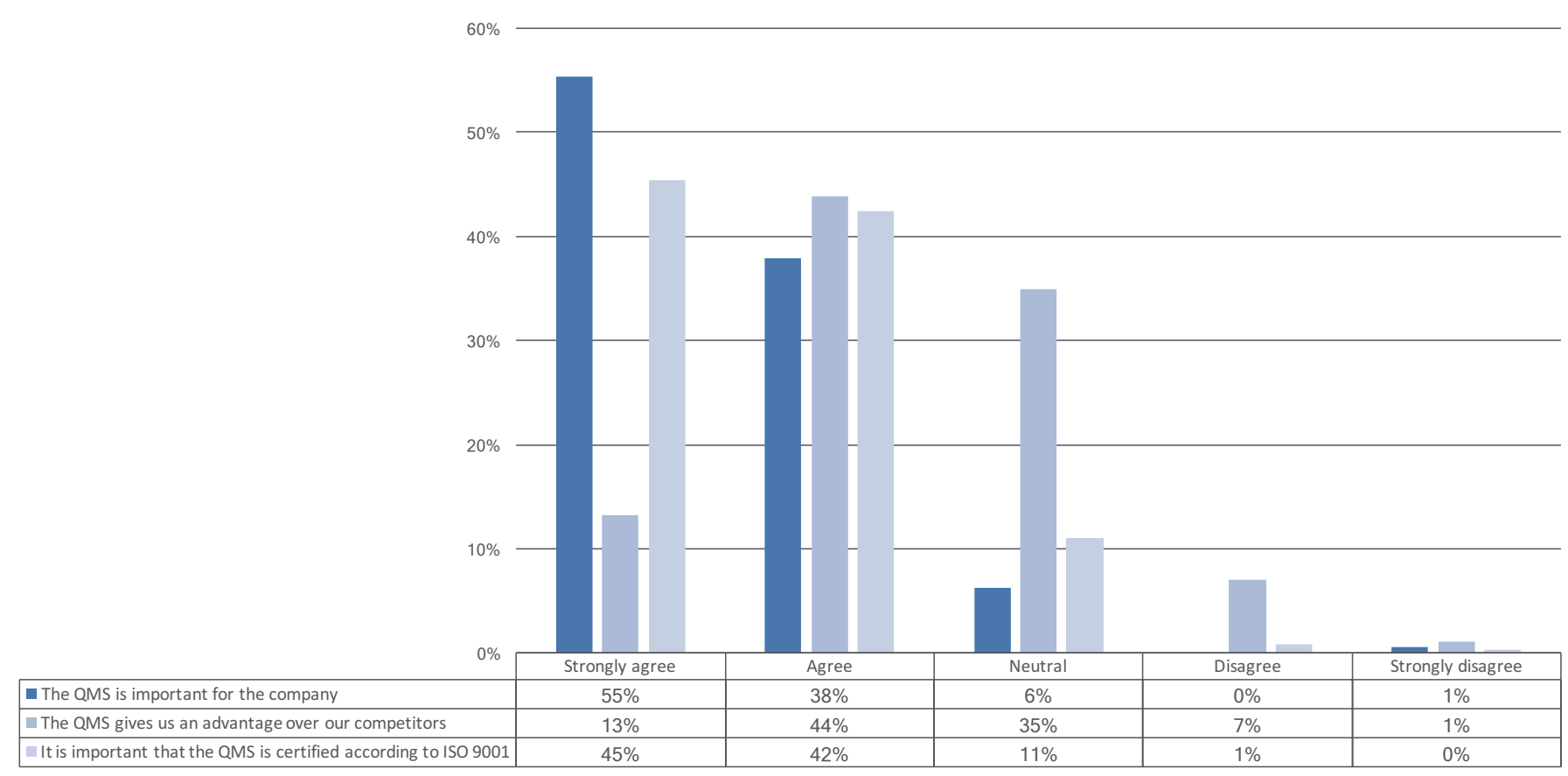

Figure 2 Results from employee survey - answers to statements that relate to the company.

while $3 \%$ disagree. $68 \%$ of the employees agree or strongly agree with the statement that the QMS enables their organisation to better meet the needs of their customers, $28 \%$ are neutral, while $4 \%$ disagree or strongly disagree. $56 \%$ of the employees agree or strongly agree with the statement that their organisation runs a QMS because of requirements from their customers, $32 \%$ are neutral, while $12 \%$ disagree or strongly disagree (Figure 1).

$93 \%$ of the employees agree or strongly agree with the statement that the QMS is important for the company, $6 \%$ are neutral, while $1 \%$ strongly disagree. $57 \%$ of the employees agree or strongly agree with the statement that the QMS gives an advantage over competitors, 35\% are neutral, while $8 \%$ disagree or strongly disagree. $87 \%$ of the employees agree or strongly agree with the statement that it is important for the organisation to have the QMS certified, $11 \%$ are neutral, while $1 \%$ disagree or strongly disagree (Figure 2 ).

\subsection{Interviews with representatives of clients of the engineering consultancies}

Five representatives of very large clients of engineering services were interviewed. All of them are public organisations, three operating on a national basis and two operating in Reykjavik city, the capital of Iceland. Interviewees with extensive 'hands on' $^{\prime}$ experience of dealing with engineers and engineering firms were identified within these organisations. The representatives of the organisations were quality managers, senior project managers or executives. The organisations are as follows:

\section{Government Construction Contracting Agency (GCCA)}

GCCA is a state agency of 25 specialists - plus support services - under the Ministry of Finance. GCCA administers government construction projects for ministries and government agencies, and undertakes consulting on technical matters, procurement and preparation of projects (GCCA, 2014). GCCA has been ISO 9001 certified since 2012.

\section{Landsvirkjun (National Power Company of Iceland)}

Landsvirkjun, which is owned by the Icelandic state, processes $75 \%$ of all electricity used in Iceland and is the country's largest electricity generator, with 330 employees. Their main clients come from the aluminium industry as well as other power-intensive industries (Landsvirkjun, 2014). Landsvirkjun has been ISO 9001 certified since Z̨Q06.VERKT/EKNI 2017/23

\section{OR - Orkuveita Reykjavíkur (Reykjavik Energy)}

$\mathrm{OR}$, a public utility provider for greater Reykjavík and other regions in the southwest and west of Iceland provides electricity, hot water for heating, cold water for consumption, as well as maintaining sewage systems. Their service area extends to 20 communities and $67 \%$ of Iceland's population (OR, 2014). The number of employees is 420 , including subsidiaries, and they have been ISO 9001 certified since 1997.

\section{RARIK (Iceland State Electricity)}

Rarik, established in 1946, is owned by the Icelandic state and is primarily a distribution company for electricity whose main purpose is the distribution of electricity to rural areas (Halldórsson, 2014). With a workforce of 200 employees, Rarik operates a QMS and is aiming for ISO 9001 certification.

\section{City of Reykjavík}

Reykjavík is the capital of Iceland, with the highest population (120.000 residents). The local administration, with 8950 employees, operates a quality manual and is working towards ISO 9001 certification (Jónsson \& Kristinsson, 2014).

\section{What requirements do your suppliers have to meet regarding QMS?}

Four of the organisations said that while they would have required it from their suppliers in the past, they do not make any such demands any more - "We do not demand any such requirements, it is so common now that the consultancies have certified QMS". The largest engineering firms mentioned in this regard were Efla, Mannvit and Verkís. The two clients that still do not have ISO 9001 certification stated that they feel that they cannot demand a certified QMS while they have not acquired one themselves. One client claimed that they make such demands - although the QMS does not have to be certified. They see it as one of their roles to be a leading force, to be a role model and believe that QMS acts to push the market forward. However, this requirement does not apply to small projects. 


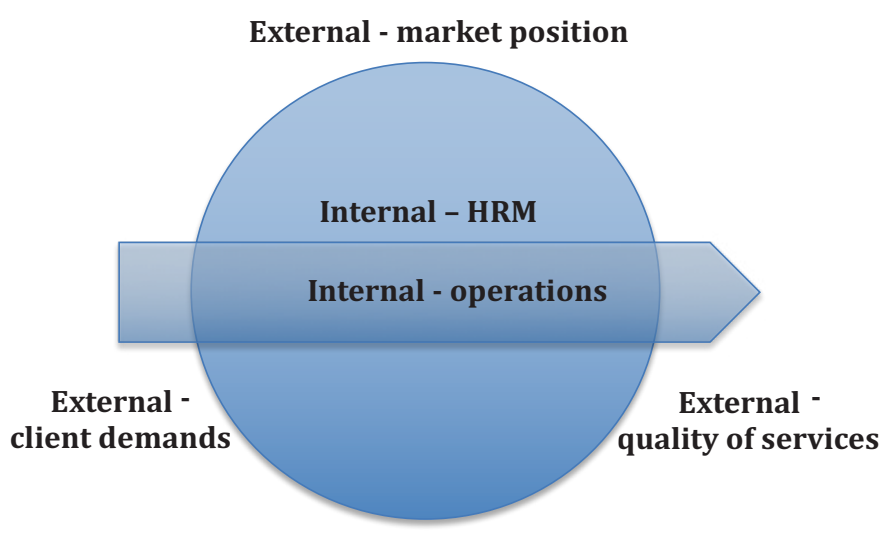

External - quality assurance

Figure 3 Six themes identified in results.

\section{When you choose consultants, how important is it for you that they have a certified QMS?}

With one exception, all of the representatives claimed that this was not important because the large engineering firms already have certified QMS. In the exceptional case, the representative claimed it is important - "It is a demand in some of our projects. If the engineering firm does not have it, it can result in them not getting the job. So if we make the demand, we enforce it".

\section{In your opinion, should only consulting firms with certified QMS get to work for your organisation?}

All the representatives stated that this depends on the size of the projects. Demanding a certified QMS is logical in larger projects, but it would be acceptable to reduce the demand in smaller projects so that smaller engineering firms, which do not have certified QMS, can be eligible.

\section{Is the quality of the work of consultancies with ISO 9001 certification in any way different from other consultancies?}

Four of the representatives said that they could not really find any difference in the service of the engineering firms with ISO 9001 certification versus noncertified. One of them said: "I have been dealing with these firms for about 20 years and I cannot see any difference. I would think that it would show within the firms rather than outwards". One of the interviewees said that it is their impression that ISO 9001 has had a positive effect. In their opinion the firms with ISO 9001 show improvement by working according to structured procedures.

\section{Have you experienced a change in the quality of services provided by an engineering consultancy, before and after becoming ISO 9001 certified?}

Two of the representatives pointed out that they were not in a position to make this comparison, because the large engineering consultancies have been ISO 9001 certified for so long. Two of the representatives said that they had not experienced a noticeable impact, but one added that he thought that the engineering firms that he has been dealing with had been exercising work methods that correspond with ISO 9001 even before receiving certification. One representative said that he had followed one of the larger engineering firms through their ISO 9001 process, and senses that this process has led to more professionalism and resulted in the company's structure and approaches becoming more assertive.

\section{What is your opinion of the ISO 9001 standard? What, if anything, has it delivered to the clients of ISO 9001 certified organisations?}

In general, the responses to this question were quite positive. The following are examples:

\author{
"I think that it is important for the larger firms to have \\ ISO 9001, especially those who are working abroad. \\ I think they would not get projects assigned without \\ having it - the demands are a lot higher".
}

\begin{abstract}
"Quality certification alone does not guarantee quality in projects. It ensures procedures and coordination, but does not deliver quality technically. However, it can do so. There is also the question of attitude/ sentiment and ambition and how the firms want to operate. But I have full confidence in these systems".
\end{abstract}

\section{DISCUSSION}

In order to create a structured overview of the feedback from the three groups, a simple classification was applied. All the feedback was classified based on the group, and whether the feedback - being a comment or a statement - reflects a motive for implementing a QMS, or the experience from operating a QMS. On the basis of this classification, six themes were identified. These themes are shown in Figure 3.

The first theme is External - client demands. Two interrelated motives are found under this theme: executives saw a certified QMS as one of the criteria in public bidding projects; and employees saw it as a requirement from clients for quality reasons. In terms of experience, clients confirm that a QMS is required in larger projects and a certified QMS is important in some projects. Furthermore, employees claim that QMS has led to increased customer satisfaction.

The second theme is External - market position. A single motive is found under this theme: executives expected that a certified QMS would make it easier to get assignments abroad, which is confirmed by their experiences. Employees pointed out that QMS certification gave their companies a competitive advantage. Finally, clients felt that QMS certification is important for the consultancies to get assignments abroad.

The third theme is External - quality assurance1. The incentive here for executives was the belief that QMS would increase their credibility with clients. This motive seems to be supported, at least partly, by experience. Employees indicated that their experience showed that certification is important. Clients, on the other hand, gave somewhat ambivalent feedback regarding this theme. On the one hand, they claimed that it is assumed that the engineering consultancies operate QMS and they pointed out that they have full confidence in their QMS. On the other hand, they stated that certification is not important and, more specifically, that QMS certification is no longer important as most of the consultancies are, in fact, certified.

The fourth theme is External - quality of services. No specific motive was defined under this theme, but two distinct experiences were identified by clients. Firstly, some stated that there was no discernible difference between the work of consultancies that have certified QMS, and those that do not, as it is not possible to detect differences in quality of services any more. Secondly, others felt that there was more professionalism to be found within certified consultancies as compared to noncertified consultancies.

1 The term is used here according to the definition of ISO 9000: "part of quality management focused on providing confidence that quality requirements will be fulfilled" (ISO 9000:2015, Clause 3.3.6). 
Motives

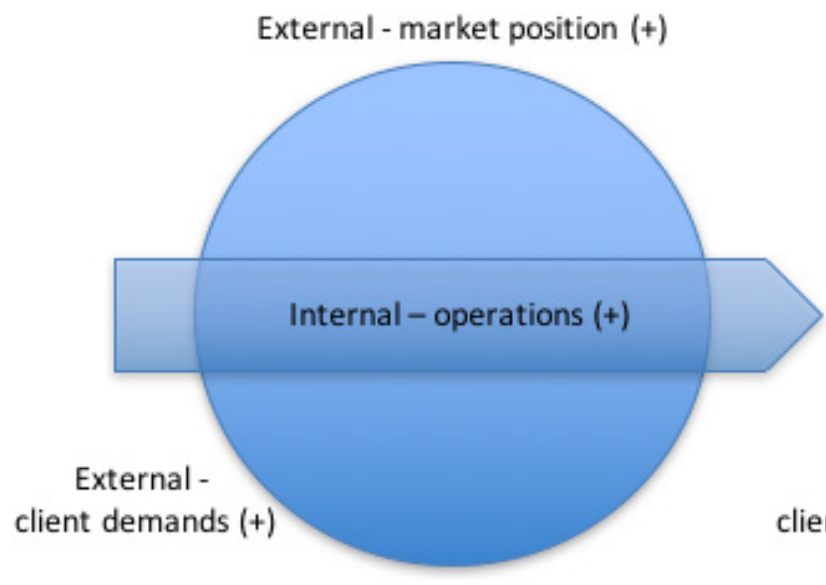

External client demands $(+$

\section{Experience}

External - market position (+)

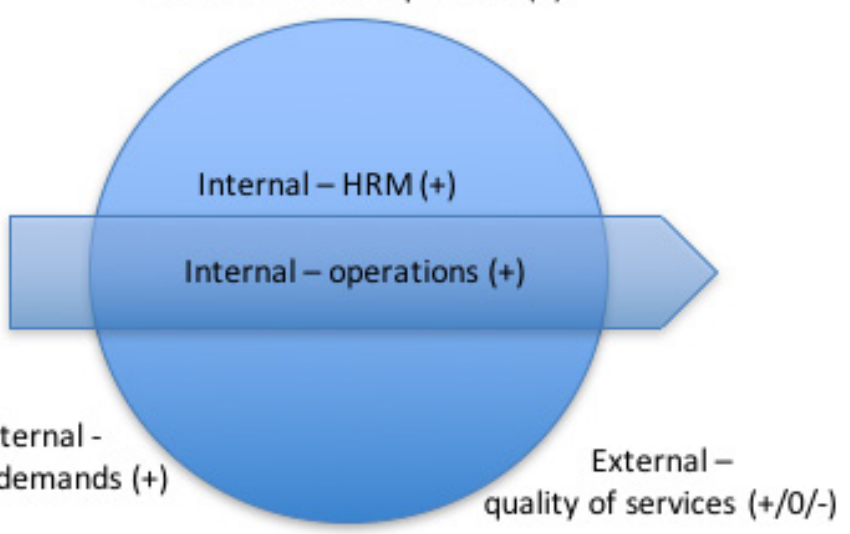

External - quality assurance (+/0/-)

Figure 4 A comparison of motives and expectations in connection with the conversion of the engineering consulting sector in Iceland to certified QMS. The signs indicate if the perceptions are positive (+), and/or neutral (0), and/or controversial (-)

The fifth theme is Internal - human resource management. No specific motive was defined under this theme, but several distinct experiences were identified. The executives claimed that employee satisfaction had increased with the implementation of QMS and stated that the employees would not like to return to how it was before the QMS was implemented. Furthermore, the executives claimed that implementing the QMS had united the employees and increased the credibility of the consultancies in the eyes of the employees. The employees confirmed this perception with positive general feedback and specifically claimed that they had a good knowledge of the QMS.

The sixth theme is Internal - operations. Important motives were specified by the executives under this theme. They saw that quality management had been acknowledged as an academic field and that ISO 9001 represented a new and practical tool. They expected to gain better coordination of procedures, which would help them to deal with increased complexity in their business environment. Their experience certainly seemed to be positive. They reported that they are running uniform management systems, leading to greater efficiency and more transparency. The employees confirmed this, claiming that having a QMS enables them to better meet the needs of their clients. An overwhelming majority of employees claim that a certification of the QMS is important. This view is also confirmed by clients, who stated that the positive effects of ISO 9001 certification can be seen in the approach of the engineering consultancies, which have more structured procedures than before.

Another way of looking at the themes is to distinguish between those relating to motives and those relating to experience. This is shown in Figure 4.

Three themes relate to 'motives' on the left of Figure 4. These are: External - market position, External - client demands, and Internal operation. In all cases, the motives are positive; they express the expectations of the executives. In contrast, all the six themes relating to 'experience' are shown on the right of Figure 4. In most cases, the experience is positive, but can be considered neutral or controversial in two themes. External - quality of services had 2 neutral or controversial items where clients pointed out that they could not see a difference in the quality of services provided by engineering consultancies with certified QMS as compared to consultancies without. Similarly, External - quality assurance had 3 neutral or controversial items, where clients claimed that a certified QMS held by the engineering consultancies is not important for them. In both cases, the reason for these views is, first and foremost, that clients no longer have the means to compare, as most of the engineering 36 VERKT/EKNI 2017/23 consultancies they use are in fact certified according to ISO 9001.

These findings are in line with the reported observation that motivational arguments are connected to marketing and sales, while the main benefits are linked to internal factors, such as operational efficiency (Urbonavicios, 2005). We find it interesting, however, that the experience of operating the QMS seems to have surpassed the expectations of the participants. An example of this is the theme human resource management which was not mentioned by the participants as a motivation for QMS implementation.

The literature indicates that a culture of quality and motivation for adopting ISO 9001 certification are predictors of the benefits and values derived from such certification. Firms which are primarily motivated to get ISO 9001 certification in order to respond to external pressure might adopt a minimalist approach to deriving certification and therefore achieve limited internal performance improvements (Terziovski et al., 2003; Singels et al., 2001). In practice, the conversion of the consulting engineering service industry in Iceland to certified QMS seems to have been successful, based on the subjective feedback from the three groups surveyed in this study. Our findings reflect a clear commitment from the executives concerned and considerable buy-in by the employees. The executives have expectations regarding the improved operation of their companies, in addition to meeting client expectations and strengthening their market position. These observations imply that industry has managed to avoid the most important barriers to successful implementation of ISO 9001 as reported by Al-Najjar and Jawad (2011) and Sampaio et al. (2009).

The engineering consultancies appear content with their QMS certification. But what about the clients? Olafsdottir (2011) concluded that there is a positive correlation between client's satisfaction and whether their contractors are working in accordance with QMS. Our study implies a different situation. Operating QMS does not seem to result in more customer satisfaction. What does this mean? The engineering consultancies have been operating certified QMS for some time. This is already taken for granted by the clients. In a way, the consultancies have long ago 'reaped the benefits' of certified QMS, as seen from the narrow perspective of market position. We feel that this general observation is in line with the findings of Brynjarsdottir (2016) who concluded that when companies select contractors, they look primarily at price and operating a QMS does not give the contractors any notable advantage, in the eyes of the clients.

We point out that if the clients do not experience any noticeable improvement from their certified providers of engineering services, 
this may indicate a flaw in continuous improvement within the industry. Continuouse improvement is a fundamental theme in the ISO 9001 standard and stressed further in the 2015 version with the explicit application of the PDCA cycle (ISO, 2015). The engineering consultancies need to be proactive in their improvement efforts, and continuously improve their quality systems. They should make the benefits of this known to management, employees and clients.

\section{CONCLUSIONS}

This study provides an overview of the motives and perceived experiences relating to the conversion of much of the consulting engineering industry in a European country - Iceland - to the use of certified ISO 9001 based quality management systems as a framework for their activities. The conclusions reached here are based on feedback from the vast majority of consulting engineers in the country, the most important engineering consultancies, and key large public clients.

The main motives for implementing Quality Management Systems in the engineering consultancies were to respond to demands by the clients, improve their market position (QMS) and improve their operations. All of these benefites have been realised and in addition, they have eperienced increased employee satisfaction as a consequence of implementing QMS.

The employees of the engineering consultancies are very positive when asked about their attitudes towards QMS. They feel that operating QMS leads to a competetive advantage and enhanced ability to meet the needs of the customer.

To sum up, the executives and the employees of the engineering consultancies surveyed claim that the conversion has been successful - the expectations of the engineering consultancies have been met and exceeded in important areas. The perceptions of the clients, on the other hand, are more ambivalent. Certified QMS is seen as being important by some clients and it is considered a logical condition in larger projects by all clients. It seems, however, that certified QMS is now taken for granted by the clients and little specific gratification is expressed by the clients in this context. One can conclude that operating a certified QMS is a prerequisite for the engineering consultancices, but does not lead to any competetive advantage.

This may be an indication that the consultancies run their QMS as 'business as usual' and are not active in their continuous improvement work. If this is the case, they fail to take advantage of one of the key elements of ISO 9001 as a framework to foster continuous improvement. This possibility is worth investigating further, both in the engineering consultancy industry and in fact in ISO 9001 certified organisations in general.

\section{REFERENCES}

Aarts F. M. \&Vos E. (2001).The impact of ISO registration on New Zealand firms' performance: a financial perspective. TQM Magazine, 13(3), 180-191.

Al-Najjar, S. M., \& Jawad, M. K. (2011).ISO 9001 Implementation Barriers and Misconceptions: An Empirical Study. International Journal of Business Administration, 2(3).

Beirã G. \& Sarsfield C. J. (2002).The reaction of the Portuguese stock market to ISO 9000 certification. Total Quality Management, 13(4), 465-474.

Brynjarsdottir, B. (2016). A review of contractor selection methods in Iceland: Risky business? MSc thesis at the School of Science and Engineering, Reykjavik University.

Chow-Chua C., Goh M. \& Wan B. T. (2003). Does ISO 9000 certification improve business performance? International Journal of Quality \& Reliability Management, 20(8), 936-953.

Corbett C. J., Montes-Sancho M. J. \& Kirsch D. A. (2005). The Financial Impact of ISO 9000 Certification in the United States: An Empirical Analysis. Management Science, 51(7), 1046-1059.

Dimara E., Skuras D., Tsekouras K. \&Goutsos S. (2004). Strategic orientation and financial performance of firms implementing ISO 9000. The International Journal of Quality \& Reliability Management, 72-89.
Efla (2014). Retrieved April 26th 2016 from www.efla-engineers.com.

EU (2014). Retrieved on May 3rd 2014 from http://ec.europa.eu/enterprise/ policies/sme/facts-figures-analysis/sme-definition/index_en.htm.

FIDIC (2001). Guide to the interpretation and application of the ISO 9001:2000 standard for the consulting engineering industry. Lausanne, Romandy, Switzerland: Fédération Internationale des Ingénieurs-Conseils (FIDIC).

GCCA (2014). FSR - Government Construction Contracting Agency,

Retrieved on April 26th 2014 from www.fsr.is/English.

Gunnlaugsdóttir J. (2010). Vottað gæðakerfi - Hvatar og áskoranir. Pjódarspegillinn 2010. Félagsvísindastofnun Háskóla Íslands.

Heras I., Casadesús M., \& Ochoa C. (2001). Effects of ISO 9000 certification on companies' profitability: an empirical study. Integrated Management: Proceedings of the 6th International Conference on ISO 9000 and TQM, 60-65.

Heras I., Dick G. P., \& Casadesus M. (2002). ISO 9000 registration's impact on sales and profitability: A longitudinal analysis of performance before and after accreditation. The International Journal of Quality \& Reliability Management, 774-791.

Hrobjartsson A., Ingason H. T. \& Jonasson H.I. (2013). Financial benefits of an ISO 9001 certification (in Icelandic). Verktaekni Journal of the Icelandic Association of Chartered Engineers, 2014/20, p. 39 - 43.

Ólafsdóttir, A. H. (2011). Áhrif gæðastjórnunar á mannvirkjagerð. MSc thesis, University of Iceland. Retreived from http://skemman.is/item/view/1946/9874

ISO (2017). ISO 9000 - Quality management. Retrieved on June 2nd 2017 from ISO: https://www.iso.org/iso-9001-quality-management.html

ISO (2015). ISO 9000:2015 Quality Management Systems - Fundamentals and vocabulary. Geneva, Switzerland: ISO/IEC.

ISO (2015). ISO 9001:2015 Quality Management Systems - Requirements. Geneva, Switzerland: ISO/IEC.

Landsvirkjun (2014). Retrieved on April 26th 2014 from www.landsvirkjun. com/company

Lima M., Resende Marcelo \& Hasenclever L. (2000). Quality certification and performance of Brazilian firms: An empirical study. International Journal of Production Economics, 66, 143-157.

Mannvit (2014). Retrieved on April 26th, 2014 from www.mannvit.com.

Martínez-Costa M., \& Martínez-Lorente A. R. (2003). Effects of ISO 9000 certification on firms' performance: A vision from the market. Total Quality Management \& Business Excellence, 14(10), 1179-1191.

Naser K., Karbhari Y. \& Mokhtar M. Z., (2004). Impact of ISO 9000 registration on company performance: Evidence for Malaysia. Managerial Auditing Journal, 509-516.

Orkuveita Reykjavikur (2014). Retrieved on April 26th 2014 from www.or.is/ en/services

Sampaio, P., Saraiva, P., \& Rodrigues, A. G. (2009).ISO 9001 certification research: questions, answers and approaches. International Journal of Quality \& Reliability Management, 26(1), 38-58.

Sellers, R. \& Nicolau, J. L. (2002). The stock market's reaction to quality certification: Empirical evidence from Spain. European Journal of Operational Research, 142(3), 632-641.

Singels J., Ruel G. \&Water H.V. (2001). ISO 9000 series - Certification and performance. The International Journal of Quality \& Reliability Management, 62-75.

Tang, S. L., \& Kam, C. W. (1999).A survey of ISO 9001 implementation in engineering consultancies in Hong Kong. The International Journal of Quality \& Reliability Management, p. 562-574.

Terziovski M., Power, D. \& Sohal A. S. (2003). The longitudinal effects of the ISO 9000 certification process on business performance. European Journal of Operational Research, 580-595.

Thordarson, S. (2002). Frumherjar í verkfræði á Íslandi (in Icelandic). Reykjavik: Icelandic Association of Chartered Engineers.

Urbonavicius, S. (2005). ISO system implementation in small and medium companies from new EU member countries: A tool of managerial and marketing benefits development. Research in international business and finance, 19(3), 412-426.

Verkís (2014). Retrieved on April 26h 2014 from www.verkis.com.

VSB (2014). Retrieved on April 26th 2014 from www.vsb.is.

VSO (2014). Retrieved on April 26th 2014 from www.vso.is/english2/home.html.

Wayhan, V. B., Kirche, E. T., \& Khumawala, B. M. (2002). ISO 9000 certification: The financial performance. Total Quality Management, 13(2), 217-231.

Zeng, S. X., Tian, P., \& Tam, C. M. (2007). Overcoming barriers to sustainable implementation of the ISO 9001 system. Managerial Auditing Journal, 22(3), 244-254

\section{ACKNOWLEDGEMENTS}

The authors would like to thank all participants in this research for their support and participation. 